\title{
Crowdfunding: An Alternative Method to Invest
}

\author{
Ferdinando Giglio ${ }^{1}$ \\ ${ }^{1}$ Department of Economics, University of Campania "Luigi Vanvitelli”, Capua, Italy \\ Correspondence: Ferdinando Giglio, PhD at University of Campania "Luigi Vanvitelli" Corso Gran Priorato di \\ Malta, 1, Capua, 81043, Italy \\ Received: January 3, 2022 \\ Accepted: January 28, 2022 \\ Online Published: January 31, 2022 \\ doi:10.5539/ibr.v15n3p13 \\ URL: https://doi.org/10.5539/ibr.v15n3p13
}

\begin{abstract}
Crowdfunding platforms can be used by individuals both to launch fundraising campaigns and to invest their savings.

Crowdfunding is a funding channel through which personal or professional projects of individuals and small businesses can be directly funded by a multitude of entities. The meeting between supply and demand takes place on online platforms that provide information on individual projects and manage the flows of money.

Crowdfunding is an alternative financing channel to that represented by banks or other financial intermediaries. The actual financing of a project, in fact, does not depend on the evaluation made by a single intermediary based on its own financing strategies but on the ability of the proponents to convince a sufficient number of investors to risk their funds in direct support of the initiative.
\end{abstract}

Keywords: Crowdfunding

\section{Introduction}

People can get cash through crowdfunding which is an alternative investment method. (Agrawal e Kleeman, 2013). Entrepreneurs find many opportunities in investing in crowdfunding. (Belleflamme e Moritz, 2016).

As several studies show, this phenomenon is growing rapidly. In fact, in 2012, 2.7 billion dollars were granted, which became 5.1 in 2013 (Massolution, 2013).

Crowdfunding is essentially based on web 2.0 (Leimeister, 2012).

Crowdfunding platforms offer project promoters the opportunity to apply for funding for their initiatives (Mollick, 2014). Kickstarter.com is one of the platforms used to promote a project. investors, therefore, create an online project on these platforms and provide information and descriptions on the latter.

If funding is achieved, members are obligated to deliver on the promised funding (Etter et al., 2014). Conversely, when the funding is not reached, the project is not subsidized.

The article is set up as follows: after having illustrated the main definitions of crowdfunding and illustrated the activities carried out by the actors involved, the main models of this phenomenon are described. After that, the benefits and risks that crowdfunding implies are presented. In the last part, the main crowdfunding model is presented, useful for entrepreneurs and investors when they decide to present a new project.

\section{Definitions of Crowdfunding}

The term crowdfunding consists of two words: "crowd" and "outsourcing" (Kleeman et al., 2008). The first to define crowdfunding, in a 2006 article, was Howe (2009) and, to date, his definition remains the most important (Brabham, 2009; Starbird, 2012).

According to Howe's definition, crowdfunding is considered as "the act of taking on the task of an established agent and outsourcing it to an indefinite number of people" (Howe, 2006b, page 1).

Mollick's (2014) definition is also fundamental. According to this author, this phenomenon indicates "the efforts made by people to finance their projects by drawing on the resources of individuals who use the Internet" (Mollick 2014, p. 2).

The following table (Table 1) shows some of the main definitions of the term crowdfunding. 
Table 1. Crowdfunding

\begin{tabular}{|l|l|}
\hline $\begin{array}{l}\text { Authors who define } \\
\text { crowdfunding }\end{array}$ & Description \\
\hline Belleflamme, 2009 & Crowdfunding provides an open call for the provision of money. \\
\hline Fielder, 2013 & $\begin{array}{l}\text { Crowdfunding refers to companies seeking capital which, through offers, ask a group of } \\
\text { investors to make loans. }\end{array}$ \\
\hline Hemer, 2012 & Crowdfunding finances projects through micropayments. \\
\hline Lambert, 2011 & $\begin{array}{l}\text { Crowdfunding in an open call for the provision resources for the right to vote in order to } \\
\text { support projects for specific purposes. }\end{array}$ \\
\hline Tomczak, 2012 & $\begin{array}{l}\text { Crowdfunding is the act of borrowing resources from an agent and outsourcing it to a group of } \\
\text { people. }\end{array}$ \\
\hline Voorbraak, 2012 & $\begin{array}{l}\text { Crowdfunding is a process by which many people request resources to finance a project that } \\
\text { can have both a monetary and a non-monetary return. }\end{array}$ \\
\hline Wenzlaff, 2013 & Crowdfunding raises funds to finance projects through web 2.0 platforms. \\
\hline
\end{tabular}

All these definitions agree that crowdfunding mainly focuses on raising capital from different individuals, using platforms on the Internet (Yang et al., 2009).

\section{Actors Involved in Crowdfunding}

The people involved in this phenomenon are: intermediaries, fundraisers and investors (Tomczak and Brem, 2013).

Interlocutors play a fundamental role which consists in combining fundraising (Zvilichovsky et al., 2013). They also create a platform through which they communicate information. (Brabham e Estellés-Arolas, 2012). Intermediaries vary in their focus. Acquisition and sale are the main communication channels. (Kaganer et al., 2014). Social networks, such as Facebook and Twitter, are also used as platforms to obtain helps (Belleflamme, 2010).

Fundraising, on the other hand, includes individuals seeking funding.

Among companies, industries, institutions and non-profit organization, the company is the favorite type of fundraising (Moritz and Block, 2014).

In order to start a project, companies must receive funding applications (Belleflamme et al., 2011) which can decide whether or not to accept the project.

The main purpose of fundraising is to receive funding.

Finally, there are the investors who are the ones who choose whether to financially support these projects (Ordanini et al., 2011).

Investors are presented as registered indirect users with access to project information (Baba et al., 2014).

\section{Models of Crowdfunding}

The best known crowdfunding models are: crowdfunding focused on donation, reward and finally the one based on loan and equity (Parhankangas, 2018).

In the first type of model, backers provide funding without expecting any return. Contributions to public goods are subsidized by this model (Parhankangas et al. 2019). Typical platforms of this model are Justgiving and Gofundme.

In reward-based crowdfunding, on the other hand, supporters of a project provide financial support in exchange for an advantage (Belleflamme et al. 2014). Typical platforms of this model are Kickstarter.com and Indiegogo.com.

In addition, in loan-based crowdfunding, investors provide funds to small businesses expecting repayment within a specified time (Guo et al. 2016). Typical platforms for this model are: Kiva and Fundingcircle.

In the latest type of crowdfunding, namely the one based on equity, institutional investors buy the capital of new projects or enter into an agreement with a industry (Deffains-Crapsky and Ahlers, 2016). The platforms of this model are: Wefunder and Localstake.

\section{Benefits and Risks Present in Crowdfunding Models}

In the four models described above, there are different reasons that push an investor to choose one of them. 
In the model based on the donation,empirical research shows that altruism favors contributions (Burtch et al. 2013).

In the model based on the reward, however, the motivation would tend to mix between the desire for gifts and the feasibility of the idea published on the website (Gerber et al., 2012).

In addition, in loan-based crowdfunding, studies show that the behavior of supporters depends on pro-social motivations (Allison et al., 2013).

Finally, in equity-based crowdfunding, it has been found that the reasons why an investor chooses this model is that there can be financial returns (Cruz, 2017).

In addition to the advantages that this phenomenon presents, there are also some risks.

First of all, time, because fundraising campaigns require the execution of a series of different tasks, including understanding the platform requirements, or planning and creating a video pitch (Cruz, 2017).

Another concern is related to the need to show the project to people. To do this, entrepreneurs should show the public accurate news about the project. The risk of similarity increases due to the transparency of the information (Hommerová 2020).

Information asymmetry occurs when a subject has more information than another subject (André et al. 2017).

\section{Main Model of Choice}

The model presents the structure of a dynamic game. This game takes place in a discreet environment with two interdependent agents: the entrepreneur and the investors. The time is equal to: $t \in[0, T], T_{d}$ s.t. $T_{d} \geq T$.

At the time equal to At $t=0$, the entrepreneur realizes all the exogenous parameters and fixes the endogenous ones. The game ends in the time equal to At $t=T$.

If the loan is successful, the products are delivered to investors when $t=T_{d}$.

The entrepreneur has a certain financial need to carry out the project. For this reason, he sets prices, costs and quantitative controls in order to maximize the probability that $S_{t}>K$ s.t. $K-$ costs $\geq F$.

Donations, active and passive investments are the three investment opportunities offered by entrepreneurs. While through donations and passive investments, investors are guaranteed the opportunity to passively participate in the project, with active investments they are granted the opportunity to participate actively. Active and passive participation is represented through fixed costs: $c^{P I}$ and $c^{A I}$.

Active and passive investments include a margin cost for the entrepreneur equal to $c^{P}$. Entrepreneurs, more often than not, institute quantitative controls referred to as $Q^{P I}$ and $Q^{A I}$. Donations, passive and active investments are offered at fixed prices respectively equal to: $p^{D}, p^{P I}$, and $p^{A I}$.

The investor's main objective is the maximization of utility. This maximization can take place through four ways: donation, passive investment, active investment or wait and do nothing until $t+1$. They are referred to as: $A_{i, t}=D, P I, A I$, or $W A I T$. When an investor decides to invest, he must be aware of current and past 
states; he must also be aware of prices, costs, times and quantity controls. The number of investments made prior to the decision represent the state of the game. These measures are referred to as: $q_{t}^{D}, q_{t}^{P I}, q^{A I_{t}}$, and $S_{t}=p^{D} q_{t}^{D}+p^{P I} q_{t}^{P I}+p^{A I} q_{t}^{A I}$

Through these forecasts, linear forecasts are developed. These forecasts will be useful for probability estimates, which will be evaluated as follows:

$$
\begin{gathered}
P_{t, t+1}^{P I}=\max \left(0, \min \left(1, \frac{1}{Q^{P I}}\left(\frac{q_{t-1}^{P I}-q_{t-3}^{P I}}{3}+q_{t}^{P I}\right)\right)\right) \\
P_{t, t+1}^{A I}=\max \left(0, \min \left(1, \frac{1}{Q^{A I}}\left(\frac{q_{t-1}^{A I}-q_{t-3}^{A I}}{3}+q_{t}^{A I}\right)\right)\right) \\
P_{t, T}^{S}=\max \left(0, \min \left(1, \frac{1}{K}\left(\frac{S_{t-1}-S_{t-3}}{3}(T-t)+S_{t}\right)\right)\right)
\end{gathered}
$$

Equations (1) and (2) indicate the probabilities with which passive and active investments will "sell out" between $\mathrm{t}$ and

$t+1$. Equation (3), on the other hand, describes the probability through which the total amount raised exceeds the funding threshold at $\mathrm{t}=\mathrm{T}$.

There comes a time when the investor has to make a decision. To decide, consider among the following opportunities:

\section{1) Value of donation}

2) Value of Passive Investment

$$
\begin{aligned}
& V_{i, t}^{D}=P_{t, T}^{S}\left(\beta_{i} c^{P I}-p^{D} \delta^{T-t}\right) \\
& \quad\left(\text { if } q_{t}^{P I}<Q^{P I}\right)
\end{aligned}
$$

$$
\begin{aligned}
V_{i, t}^{P I} & =P_{t, T}^{S}\left(\beta_{i} c^{P I}+\alpha_{i} c^{P} \delta^{T_{d}-t}-p^{P I} \delta^{T-t}\right) \\
& \left(\text { if } q_{t}^{A I}<Q^{A I}\right)
\end{aligned}
$$

3) Value of Active Investment

$$
\begin{aligned}
& V_{i, t}^{A I}=P_{t, T}^{S}\left(\gamma_{i} c^{A I}+\alpha_{i} c^{P} \delta^{T_{d}-t}-p^{A I} \delta^{T-t}\right) \\
& \quad(\text { if } t<T)
\end{aligned}
$$

4) Value of Waiting

$$
V_{i, t}^{W}=\max \left\{\begin{array}{l}
0, \\
\delta^{-1} P_{t, T}^{S}\left(\beta_{i} c^{P I}-p^{D} \delta^{T-t+1}\right), \\
\delta^{-1} P_{t, T}^{S}\left(1-P_{t, t+1}^{P I}\right)\left(\beta_{i} c^{P I}+\alpha_{i} c^{P} \delta^{T_{d}-t+1}-p^{P I} \delta^{T-t+1}\right) \\
\delta^{-1} P_{t, T}^{S}\left(1-P_{t, t+1}^{A I}\right)\left(\gamma_{i} c^{A I}+\alpha_{i} c^{P} \delta^{T_{d}-t+1}-p^{A I} \delta^{T-t+1}\right)
\end{array}\right.
$$

(if $A_{i, t-1}=W$ ait i.e. player is active) 


\section{5) Action}

$$
A_{i, t}=\max \left\{\begin{array}{l}
V_{i, t}^{D}, \\
V_{i, t}^{P I}, \\
V_{i, t}^{A I}, \\
V_{i, t}^{W} .
\end{array}\right.
$$

The game ends when $t>T$.

\section{Conclusion and Limitations}

The following work aimed to present the crowdfunding phenomenon. This phenomenon has met with great success in recent times.

The actors involved in this phenomenon are: intermediaries, fundraisers and investors.

It is a collaborative process of a group of people using their money together to support the efforts of individuals and organizations. It is a bottom-up microfinance practice that mobilizes people and resources.

The work also has limitations: crowdfunding is not the only model for applying for a loan; then other models could be analyzed.

\section{References}

Alegre, I., \& Moleskis, M. (2016). Crowdfunding: A review and research agenda. Working Paper, 1-38. https://doi.org/10.2139/ssrn.2900921

Brian, J. (2011). Crowdfunding: Disintermediated Investment Banking. Advanced Finance Seminar, 1-20. Retrieved from https://mpra.ub.uni-muenchen.de/31649/

Chervyakov, D., \& Rocholl, J. (2019). How to make crowdfunding in Europe. Retrieved from http://hdl.handle.net/10419/208041

Kock, A., \& Siering, M. (2015). Crowdfunding success factors: The characteristics of successfully funded projects on crowdfunding platforms. Twenty-Third European Conference on Information Systems, 1-15. Retrieved from https://ssrn.com/abstract=2808424

Malvine, K., Ricarda, B., \& Sascha, K. (2015). Crowdfunding: The Current State of Research. International Business \& Economics Research Journal, 14(3), 407-416. https://doi.org/10.19030/iber.v14i3.9206

Nur, A., \& Mohd, R. (2016). Crowdfunding: a collaborative waqf based internet platform. International Journal of Business, Economics and Law, 11(5), 41-46.

Susana, B., \& Freitas, J. (2020). Crowdfunding: An Exploratory Study on Knowledge, Benefits and Barriers Perceived by Young Potential Entrepreneurs. Journal of Risk and Financial Management, 13(81), 1-24. https://doi.org/10.3390/jrfm13040081

\section{Copyrights}

Copyright for this article is retained by the author(s), with first publication rights granted to the journal.

This is an open-access article distributed under the terms and conditions of the Creative Commons Attribution license (http://creativecommons.org/licenses/by/4.0/). 